\title{
TAXATION OF ADVANCE RECEIPTS FOR FUTURE SERVICES
}

\author{
Johannes R. KRahmeR*
}

SOUND ADMINISTRATION of the federal income tax laws requires that a definitive standard or set of rules be set forth as to when a taxpayer who has received payments for services to be rendered in a future tax period must report income from such a transaction. To date, no such definitive standard is present, as testified to by recent contrasting decisions emanating from the federal appellate and lower courts. Although the subject has been frequently discussed by commentators, ${ }^{1}$ it is believer that a re-examination of the problem from a fundamental viewpoint will help to clarify the issues. The article further makes recommendations for a workable and practical resolution of the problem, consistent with the interests of taxpayers and the Treasury alike.

\section{The Problemi}

It is well to begin by simply illustrating what the basic problem is and under what factual circumstances it can arise. Basically, the problem occurs whenever payment is made to an accrual basis taxpayer in a taxable period prior to that during which the taxpayer will render performance with respect to that item of receipt. Thus, the problem would occur if $X$, the owner of a jeep with a snowplow attachment, were paid $\$ 100$ in the middle of a taxable year to remove snow from a certain area during the next year. The problem also would occur if $Y$ Company were paid $\$ 1,000,000$ in year $I$ to build a missile, the construction

*A.B. 1953, Dartmouth College; LL.B. 1959, Harvard University. Member of the District of Columbia bar.

${ }^{2}$ For some of the more thoughtful recent articles, see Behren, Prepaid IncomeAccounting Concepts and the Tax Law, 15 TAX L. Rev. 343 (1960); Bicrman \& Helstein, Accounting for Prepaid Income and Estimated Expenses under the Interval Revenue Code of 1954 , 10 Tax L. Rev. 83 (1954); Emery, Time for Accrual of Income and Expenses, in N. Y. U. 17TH INsT. ON FED. TAX. 183 (1959); Freeman, Tax Accrual Accounting for Contested Items, $56 \mathrm{MrCH}$. L. REv. 727 (1958); Jacobs, Changing Attinudes Toquard Accrual Concepts, in N. Y. U. I6TH INsT. ON FED. TAx. 579 (1958); Rothaus, $A$ Critical Analysis of the Tax Treatment of Prepaid Income, 17 MD. L. REv. $121(1957)$. 
of which were to take place in year 2. In which year should $X$ 's $\$ 100$ receipt or $Y$ Company's $\$ 1,000,000$ receipt be reflected in income? Should the answer be the same for both? This is the simplest phase of the problem.

Most of the controversy in the area does not involve single payment problems as those shown above. Usually, a taxpayer in this type of situation receives a series of payments for services to be rendered during future periods. Thus, borrowing a simple set of facts from a recent decision, ${ }^{2}$ suppose that $Z$ operates a dancing school and offers to prospective students a contract for twenty-four lessons at a total price of $\$ 240$. Payment is made by a $\$ 100$ down payment and $\$ 20$ per month for seven months thereafter. A student enrolls on August I under this plan. At the end of year $\mathrm{r}, Z$ has given the student ten lessons and the student has paid $Z \$ 180$. What amount should $Z$ include in his income for year I? Before $Z$ files his year I income tax return, he has given the student ten more lessons and collected $\$ 40$ more. Should these added facts be taken into account in reporting gross income for year $I$ ?

The position of the Internal Revenue Service, in the cases of $X$ and $Z$, is that the entire amount received is includible in gross income when received, irrespective of when the services will be rendered for which the payments were made. The Service takes this position even though the taxpayers involved report on the accrual rather than cash basis. The practical reason for this position is to maintain the current flow of revenue into the public treasury. In other words, the Treasury wants the revenue now-not later. The taxpayer, on the other hand, does not want to pay an income tax until he has ascertained what income, if any, will arise from the transaction. In some cases, there may exist a controversy not only as to the time for payment of the tax, but also as to the amount of tax due. Such cases occur where the taxpayer is subject to graduated rates, for the postponement of recognition of gross income would result in a more even spreading of deductions.

\section{II}

\section{The Statutory Basis}

The best place to begin any analysis of a tax problem is with the governing statutory provisions. Although this precept may seem too obvious to deserve mention, many recent decisions in this area, as will be seen presently, show a remarkable lack of concern for the statutory

\footnotetext{
"Schlude v. Commissioner, $2 s_{3}$ F.zd 234 (sth Cir. 1960).
} 
language. In order to be firmly grounded, the governing statutory provisions are set forth in full. For the sake of keeping current, the 1954 Code provisions are quoted; they are in relevant respects identical to the prior Code provisions under which most litigation has occurred;"

\section{SEC. 446. GENERAL RULE FOR METHODS OF ACCOUNTING}

(a) General Rule.-Taxable income shall be computed under the method of accounting on the basis of which the taxpayer regularly computes his income in keeping his books.

(b) Exceptions.-If no method of accounting has been regularly used by the taxpayer, or if the method used does not clearly reflect income, the computation of taxable income shall be made under such method as, in the opinion of the Secretary or his delegate, does clearly reflect income.

(c) Permissible Methods.-Subject to the provisions of subsections (a) and (b) a taxpayer may compute taxable income under any of the following methods of accounting-

(I) the cash receipts and disbursements method;

(2) an accrual method;

(3) any other method permitted by this chapter; or

(4) any combination of the foregoing methods permitted under regulations prescribed by the Secretary or lis delegate.

SEC. 45I. GENERAL RULE FOR TAXABLE YEAR OF INCLUSION.

(a) General Rule.-The amount of any item of gross income shall be included in the gross income for the taxable year in which received by the taxpayer, unless, under the method of accounting used in computing taxable income, such amount is to be properly accounted for as of a different period.

To the uninitiated reader, the rules set forth in these sections appear to be relatively clear: Section $446(a)$ states the general rule for computation of taxable income-namely, the method of accounting used by the taxpayer in keeping his books. Section $446(\mathrm{~b})$ provides that in two. instances, the Commissioner may require a different computation, one that, in his opinion, clearly reflects income. These are, if: (I) no method of accounting has been regularly employed by the taxpayer; or (2) the method regularly employed does not clearly reflect income. Section 446(c) specifically sanctions the use of certain accounting methods, subject to the restrictions above, one of which is the accrual method. Section 45I(a) states a general rule for one of the particular type of situations that is the focus of this article-the time of inclusion

\footnotetext{
${ }^{3}$ Int. Rev. Code of 1939, ch. $x, \S \S 41 \& 42,53$ Stat. 24 (1939).
} 
of items of gross income. Here, the general rule is that the time of inclusion is the time of receipt, unless the method of accounting permitted under section 446 specifies otherwise.

Throughout these statutory provisions, reference is made to "methods of accounting." A method of accounting, one might suppose, would be a method of keeping books and records that is used and recognized by the accounting profession. The test that the method of accounting must pass, in addition to being regularly employed, is that it must clearly reflect "income." Once again, it might be supposed that this test is one whose standards are supplied by the accounting profession, one of whose chief functions in the business community is to find and apply methods of accounting that clearly reflect income. The legislative history behind the original enactment of these statutory provisions supports this deference to the accounting profession." The Treasury Regulations also recognize the importance of established accounting practices. Thus, the Regulations under section 446 provide: 5

Sec. 1.446-I (T.D. 6282, filed 12/24/57)

General rule for methods of accounting. (a) General rule. (I) Section 446 (a) provides that taxable income shall be computed under the method of accounting on the basis of which a taxpayer regularly computes his income in keeping his books. The term 'method of accounting' includes not only the over-all method of accounting of the taxpayer but also the accounting treatment of any item. ...

(2) It is recognized that no uniform method of accounting can be prescribed for all taxpayers. Each taxpayer shall adopt such forms and systems as are, in his judgment, best suited to his needs. However, no method of accounting is acceptable unless, in the opinion of the Commissioner, it clearly reflects income. A method of accounting which reflects the consistent apphication. of generally accepted accounting principles in a particular trade or business in accordance with accepted conditions or practices in that trade or business will ordinarily be regarded as clearly reflecting income, provided all items of gross income are treated consistently from year to year.

\footnotetext{
t The House Ways and Means Committee Report contained the following statement: "As two systems of bookkeeping are in use in the United States, one based on the cash or receipt basis and the other on the accrual basis, it was deemed advisable to provide in the proposed measure that an individual or corporation may make return of income on either the cash or accrued basis, if the basis selected clearly reflects the income." H.R. REP. No. 922, 64th Cong., xst Sess. 4 (1916).

${ }^{5}$ Comparable Regulations under the 1939 Code are Treas. Reg. 1 1 8 , $\$$ 39.41-2(b), 39.4x-3 (1953).
} 
From this cursory examination of the statutory provisions involved and of the Regulations interpreting them, it would appear that the answer to our basic problem could be simply solved by recourse to the accounting authorities. If the authorities' answer is that the taxpayer is improperly reflecting income by reporting a certain figure as gross income under his method of accounting, then the Commissioner's authority to prescribe a method that, in his opinion, does clearly reflect income comes into play. ${ }^{6}$ On the other hand, if the taxpayer's method (as allowable under section 446) does, in the authorities' opinion, clearly reflect income, then the Commissioner is bound to accept the taxpayer's method.

\section{III}

\section{Business Accounting and Tax Accounting}

It should be made clear at the outset that "income" for tax purposes and "income" for business accounting purposes do not, and indeed should not, mean the same in all instances. The reason "income" cannot always mean the same for both systems is basically that each has a different function to perform, and in some instances, the implementation of one function or the other requires that different rules be applied. The function of a system of federal income taxation is to provide revenues for carrying on public functions based upon the relative earnings of various taxpaying entities in the community. A principal function of a system of business accounting is to provide disclosure as to the financial condition of a particular enterprise. The keynote of the system of taxation is fairness. The keynote of the business accounting system is conservative disclosure.

To take an obvious case where income for tax and business accounting purposes must be different because of their difference in function, suppose that a corporation contributes ten per cent of its taxable income (computed before the contribution) to charity. Only one-half of this amount may be taken as a deduction for federal income tax purposes

\footnotetext{
${ }^{6}$ This interpretation is clearly spelled out in Treas. Reg. $118, \$ 39.4$ 1-2(a) (1953), which states: "Approved standard methods of accounting will ordinarily be regarded as clearly reflecting income." This language is not present in the current Treasury Regulatious. Instead, the provision is included that: ". . . no method of accounting is acceptable unless, in the opinion of the Commissioner, it clearly reflects income." (Emphasis added.) . It is submitted that this statement in the current Regulations is misleading, since it implies that the Commissioner is given some discretionary authority to decide whether or not a method used clearly reflects income apart from the standards of the accounting profession.
} 
because of a special statutory limitation. ${ }^{\top}$ Yet, the corporation did, in fact, pay out the ten per cent amount so that its earnings are reduced by that amount. This fact must be disclosed to the business world in the form of a deduction from the corporation's income.

There are other instances where specific provisions of the Internal Revenue Code prescribe the maximum amount of deduction to which a taxpayer is entitled, no matter what business accounting would require. $^{8}$ However, the question of the proper treatment of deferred items of income for tax and accounting purposes is clearly distinguishable. No statutory provisions other than sections 446 and 45 I govern the time of inclusion of items of gross income for almost all businesses.

Since the taxpayer has the burden of proof with respect to this issue, in order to justify deferral, he has to show that accounting standards support deferral in his case. It might be imagined that accounting opinion on this issue would be sufficiently ambiguous to prevent the taxpayer from carrying his burden of proof in most cases. The remarkable fact is that the accounting profession speaks with a unanimous voice on the question. Accounting authorities agree that no income arises until goods are delivered or services rendered. To reflect the unanimity of accounting opinion on this subject, the following quotations are typical:

[A]ll customer advances are clear cut liabilities. When he deposits funds before receiving goods or services, the customer is in effect extending credit to the vendor .... Revenue arises, as the product is delivered; receipt of cash in itself does not establish the existence of revenue. ${ }^{9}$

When a customer makes a payment in advance of the service to be performed, this creates a liability on the part of the-company receiving the payment. ${ }^{10}$

The portion of revenue collected in advance that has not been earned at the end of the accounting period remains in an unearned revenue account, where it represents an obligation to be satisfied, not by the payment of money, but by the rendering of service. ${ }^{11}$

[T] he liability is for a deposit which has been made and no profit element of any kind can be recognized until service has been rendered or goods parted with. ${ }^{12}$

\footnotetext{
${ }^{7}$ Int. Rev. Code of $1954, \$ 170(b)(z)$.

${ }^{8}$ See, e.g., Int. Rev. Code of $1954, \S \S 162$ (c), $170(\mathrm{~b})$.

${ }^{-}$Paton \& Dixon, Essentials of Accounting 2 i i (1958).

${ }^{10}$ Bierman, Managerial. Accounting il 2 (1959).

"Finney \& Miller, Principles of Accounting-Introductory (1957).

${ }^{29}$ Gilman, Accounting Concepts of Profit 84 (i939).
} 
Simply stated, the accounting authorities view the receipt of money for future services as the equivalent of a loan of those funds by the customer, to be repaid at some future date by the requisite performance. ${ }^{13}$ Since it is clear that no taxable income results to the recipient of a loan, the same result should follow in the case of a receipt of money for future services. One distinction between the loan and prepaid receipt cases is that in the loan case, no income results whether the taxpayer is on the accrual or cash basis. It has been conceded that tax reporting in accordance with business accounting practices for prepaid items is available chiefly to accrual basis taxpayers. ${ }^{14}$ This article will, accordingly, confine itself to considering the problem of accrual basis taxpayers. ${ }^{15}$

The mechanics of this theory may be implemented in either of two ways. One of these is called the deferral technique, which is implemented as follows: When cash is received prior to performance, there is a debit to cash and an offsetting credit to a liability account such as deferred income or unearned income. As the services for which the advance payment was made are rendered, gross income is recognized by debiting the prepaid or unearned income account previously credited and crediting an income account. The second technique is termed the accrual technique. Under the accrual technique, when cash is received prior to performance, there is a debit to cash and a credit to an income account. However, there is also a credit made to a reserve for expense account in the amount of the estimated cost of rendering the services with respect to the item of cash received. An offsetting debit is made to an expense account. At the end of the accounting period, the income in the profit-and-loss statement will be reduced by the debit made to the expense account.

Both the deferral and accrual techniques achieve the basic accounting

${ }^{13}$ See also, Wixon \& KelL, AcCOUNTANTS' HaNDBOoK 304 (1956); KeSTER, Principles of ACCOUNTING 518 (1939).

${ }^{14}$ Mills, An Evaluation of the Accounting Provisions of the Internal Revenue Code of r954, TAX Revision Compendium 1161,1165 (1959). (This compendium is a compilation of articles written by persons invited to appear before the House Committee on Ways and Means. Mills is chairman of the Tax Committee of the American Institute of Accountants).

${ }_{15}$ The accrual system of federal income taxation has the advantage of Supreme Court blessing as regards its relation to commercial accounting principles. In United States v. Anderson, 269 U.S. 422, 440 (1926), the Court, after surveying the legislation authorizing the accrual system, concluded that its purpose was "to enable taxpayers to keep their books and make their returns according to scientific accounting principles." 
objective of matching-that is, of placing the item of receipt in the same accounting period as the item of expense related thereto. The accrual technique achieves this matching in an earlier accounting period than does the deferral technique.

The use of the accrual technique presents added theoretical as well as practical problems. On the theoretical level, the mechanics of the accrual technique work out so that a current recognition is made in income of the advance receipt (reduced, to be sure, by an expense). This current recognition does not comport with the accounting precept that no income arises until rendition of services or delivery of goods: Also on the theoretical level, the accrual technique involves taking a current deduction from income for an estimated future expense. In the federal tax sphere, this runs afoul of the oft-repeated maxim that deductions are a matter of legislative grace, and hence must be fixed and determinable.

The practical operation of the accrual technique, as opposed to the deferral technique, presents more serious problems in the federal tax area. These arise because the potential scope of the accrual technique is far broader than the deferral technique. The deferral technique can only be used where cash is received in advance of performance of services or delivery of goods with respect to such cash item. The accrual technique, on the other hand, can be used, with varying degrees of justifiability from an accounting standpoint, in a wider range of situations. Suppose that a TV dealer gave a parts warranty with each TV set sold. It seems clear from an accounting standpoint that no deferral of receipts could be justified, since the TV set has already been delivered. However, there might be some justification from an accounting standpoint for the creation of a reserve (and hence the accruing of a current expense) for the estimated cost of such parts.' Other items, such as the cost of civil suits for faulty merchandise, might be the basis for creation of a reserve from an accounting standpoint, but would not be a proper ground for deferral.

Thus, the accrual technique would entail serious problems of administration as well as added revenue loss for the Treasury. Nevertheless, it has been suggested that the accrual technique is the answer to the problem of taxation of advance receipts. ${ }^{16}$ The one advantage of this technique from the Treasury's viewpoint is that it achieves matching,

\footnotetext{
${ }^{10}$ Freeman, Offsetting Expense Accrual Should Be Allowed, 9 J. Taxation 132 (1958); 8 TAX FORTNIGHTER 1405 (1959).
} 
and hence recognition of income, earlier than does deferral. Such recognition is still far less in amount than if the total advance payment were taken into income in the year of receipt. The important point to be kept in mind is that accounting authorities agree that payments for services to be rendered or for goods to be delivered in future taxable periods cannot represent income at the time of receipt. One or the other of the two matching techniques must be used in order correctly to report income for sound business accounting purposes.

In view of these business accounting principles, and in view of the fact that the Internal Revenue Code does not purport to be a comprehensive treatise on proper accounting for tax purposes, it would appear that the statutory reference to accounting principles would dispel any argument in support of the position that amounts received for future services or future delivery of goods could be taxed as income at the time of receipt in the case of an accrual-basis taxpayer. Yet, such has by no means been the law evolved by court decisions. The presence of various additional factors and legal theories serves to complicate and confuse this area. Each of these will be discussed in turn.

\section{IV}

The Shortuived Existence of Sections 452 ANd 462 OF THE 1954 CODE

One added factor that has served to confuse this area of income taxation is the congressional enactment and subsequent repeal of sections 452 and 462 of the 1954 Code. Sections 452 and 462 were introduced into the internal revenue laws by the 1954 Code, and provided specific authorization for deferral of income and accrual of expense reserves for accrual-basis taxpayers within certain limitations. ${ }^{17}$ The legislative history of these provisions indicates a congressional dissatisfaction with court decisions that had disallowed the benefits of accrual and deferral to certain taxpayers who reported income in accordance with sound accounting practices, when the statute and regulations purportedly referred to business accounting. ${ }^{18}$

\footnotetext{
${ }^{17}$ The most important limitation was that deferral was limited to a period of five years. No limitation was imposed as to the type of prepaid income of which the taxpayer could postpone recognition.

${ }^{18}$ The House Ways and Means Committee Report contained the following statement in its general discussion of the accounting provisions: "Present law provides that the net income of a taxpayer shall be computed in accordance with the method of accounting regularly employed by the taxpayer, if such method clearly refiects the income and the
} 
However, the threatened loss of revenue from the presence of these provisions forced their repeal in June, $1955{ }^{19}$ At the time of repeal, the House Ways and Means Committee indicated that it favored income tax reporting in accordance with sound accounting principles, but that the transitional revenue loss was too great for the Treasury to bear. ${ }^{20}$ The Senate Finance Committee was especially reluctant to repeal sections 452 and 462 , and placed the blame for the large expected revenue loss on the Treasury Department for failing to exercise its authority to provide transitional rules. ${ }^{21}$ Accordingly, these sections were repealed, with the Ways and Means Committee stating that its intent was to have the law revert to the status existing prior to 1954 , to which the Treasury agreed. ${ }^{22}$

regulations state that approved standard methods of accounting will ordinarily be regarded as clearly reflecting taxable income. Nevertheless, as a result of court decisions and rulings, there have developed many divergencies between the computation of income for tax purposes and income for bnsiness purposes as computed under generally accepted accounting principles. The areas of difference are confined almost entirely to questions of when certain types of revenue and expenses should be taken into account in arriving at net income.

"The changes embodied in your committee's bill are designed to bring the incometax provisions of the law into harmony with generally accepted accounting principles, and to assure that all items of income and deductions are taken into account once, but only once in the computation of taxable income." H.R. REP. No. $1337,83 \mathrm{~d}$ Cong., $2 \mathrm{~d}$ Sess. 48 (1954).

Almost identical language is found in the Senate Finance Committee's Report, S. REP. No. I622, 83d Cong., 2d Sess. 62 (1954). In the detailed discussion of these sections, however, both Committees used language seemingly contradictory with that of the general discussions: "Under the 1939 Code, regardless of the method of accounting, with minor exceptions established by regnlations or administrative practice, amounts are includible in gross income by the recipient not later than the time of receipt if they are subject to free and unrestricted use by the taxpayer even though the payments are for goods or services to be provided by the taxpayer at a future time." H.R. REP. No. 1337, 83d Cong., 2d Sess. A159 (1954); S. REP. No. 1622, 83d Cong., 2d Sess. 301 (x954).

${ }^{10}$ Act of June $15,1955, \mathrm{ch} .143 ; 69$ Stat. $134, \S \mathrm{x}$. The Treasury estimated the loss of revenue at $\$ 47,000,000$ for 1954, and the total loss perhaps in excess of $\$$ I $, 000,000,000$. H.R. REP. No. 293, 84th Cong., 1st Sess. 3 (1955). .. .

${ }^{20}$ H.R. REP. No. 293, 84th Cong., ist Sess. 3. (1955).

${ }^{21}$ "It is because of the [Treasury] Secretary's fears and his desire to have a fresh" review of section 462 , relating to estimated expenses, and its counterpart section 452 , relating to prepaid income, and because of the House action repealing these sections that your committee has reluctantly concluded to report out the House bill repealing these sections from the effective date of their enactment. Since the Secretary has not, by regulations, exercised, the discretionary limitations which your committee delegated to him in the law, it is apparent that the loss in revenue under these provisions may be much larger than was anticipated last year." S. REP. No..372, 84th Cong., Ist Sess. 4-5 (1955).

${ }^{29}$ H.R. REP. No. 293, 84th Cong., rst Sess. 4-5 (1955); Letter from Secretary 
This pious pronouncement, seemingly innocuous enough, had the effect of throwing the law back to its uncertain and nonuniform state. Was it intended that the law revert back to the way many courts had interpreted it, or as both committees stated the courts should have interpreted it? The Senate Finance Committee was fully aware of the ambiguity created and promised early legislative action to resolve the ambiguity in favor of tax reporting in accordance with sound accounting principles. ${ }^{23}$ Unfortunately, no such legislation has been enacted.

In order correctly to interpret the congressional action with respect to sections 452 and 462 , it is helpful to illustrate the revenue effect of a transition by a taxpayer from a reporting of advances when received to a reporting based on the accrual-of-reserve or deferral techniques. Thus, borrowing the facts of the dancing school hypothetical posed earlier, if $Z$ were allowed to accrue in year I the estimated cost of lesson expenses of year 2 in addition to his year I actual expenses, then two years' expenses would be taken in year $\mathrm{I}$. This "double deduction" would only happen-once, since in year 2, the actual expenses would be charged against the previously created reserve, not resulting in added deduction (assuming the estimate correct), and the only charge would be a reserve created for estimated lesson costs in year 3. Similarly, if $Z$ were allowed to defer prepaid receipts of year $\mathrm{I}$ to year 2, which he had not been allowed to do in year 0 , then a gap in reporting of income would exist in year $\mathrm{I}$, since a portion of the receipts would be deferred with no compensating amount brought forward from year o. Again, this gap only happens once, because in year 2 , when a portion of the receipts are deferred to year 3 , an offsetting amount is brought in from year I.

of the Treasury Humphrey to Chairman of the Ways and Means Committee dated March 22, 1955, quoted id. at 5.

28 'Your committee desires to make its position clear that it expects to report out legislation dealing with prepaid income and reserves for estimated expenses at an early date. As indicated above, the existing rulings of the Treasury Department and the court decisions dealing with estimated expenses and prepaid income are now in such a state of confusion and uncertainty that in the opinion of your committee legislative action is required on these subjects. In addition, your committee believes that it is essential that the income tax laws be brought into harmony with generally accepted accounting principles. Morcover, your committee believes that the present status, where some taxpayers are able to defer prepaid income while others are not, is inequitable and should not be allowed to continue. In order to elininate this uncertainty and discrimination, definite rules must be written into the income tax law. For these reasons your committce plans to begin studies in the near future to devise proper substitutes for the sections now being repealed."' S. REP. No. 372, 84th Cong., Ist Sess. 6 (1955). 
However, an added revenue loss may, and usually does, occur in succeeding years after the transition year is passed. This happens in the case of growing businesses operating at a profit where the receipts increase in each succeeding taxable period. Here, the reserve accrued or the receipts deferred will be commensurately increased each year in advance of the receipts recognized from the previous year. This factor is not mentioned in the Committee Reports as a reason for repeal of sections 452 and 462 , although the Treasury certainly must have weighed it as an added reason for repeal.

In the light of the legislative history of these sections, perhaps the only sound conclusion as to the congressional intent is that a noble experiment was tried to bring the income tax laws into closer harmony with sound accounting principles, and it failed because of harsh economic realities. Failure of Congress to provide a transitional rule was probably the chief cause of failure. Congress realized that courts, in the absence of these provisions, were interpreting the statute contrary to sound accounting principles, which Congress disliked, but for which it was unable to formulate a workable alternative.

However, newspaper and magazine publishers managed to convince Congress in an election year that their situation with regard to prepaid subscription income was so critical that a special Code provision was necessary to deal with it. Thus, in 1958 , a new section 455 was added to the 1954 Code specifically providing for an election by the taxpayer to defer prepaid subscription income if desired. This left the anomalous situation of Congress having legislated specifically that newspaper and magazine publishers could do what, under the congressional view of the correct interpretation, supposedly all taxpayers could do anyway under the general statute. The Treasury applies to the congressional action the maxim "Inclusio unius est exclusio alterius," resulting in the construction that Congress did not wish other taxpayers to have the benefit of deferral. ${ }^{24}$ As indicated above, this construction is of doubtful validity.

The Position of the Treasury Department

The Treasury has consistently taken the position that, with a very few exceptions, amounts received by a taxpayer during a taxable period

\footnotetext{
${ }^{34}$ Brief for Defendant, pp. I1-12, American Automobile Association v. United

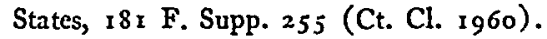


are to be included in his income no later than the period of receipt. The Treasury takes this position even though its own regulations cited previously would seem to indicate otherwise. Exceptions are made for building, installation, and construction contracts covering a period of more than one year, ${ }^{25}$ for prepaid cruise ticket receipts, ${ }^{26}$ and, of course, for prepaid newspaper and magazine subscription receipts.

Apart from the legal theories behind the Treasury's position, which will be discussed presently, there appear to be three practical reasons why the Treasury takes the position that it does. The first is the same as that advanced for the repeal of sections 452 and 462 -namely, that any wholesale postponement of recognition of income would so seriously curtail the current flow of funds into the Treasury that government functions would be seriously impeded. The second reason, which is to some degree an aggravation of the first, is that many taxpayers would invent spurious reasons for postponing recognition on the grounds that some service or another remained to be rendered in future taxable periods, when such was either not the case at all, or was not a substantially significant factor. This latter consideration would probably present added problems of tax evasion for the Treasury, and would be certain to present difficult problems of auditing returns for revenue agents. The third reason is that serious problems of collectibility would be incurred, especially in the case of individual taxpayers, if deferral over too long a period were permitted.

Lest one should become too sympathetic with the Treasury's predicament, it should be pointed out that although the Treasury rejects sound accounting principles in the case where payment precedes the rendition of services, a much more charitable attitude toward sound accounting principles is taken when the shoe is on the other foot-i.e., where the rendition of services precedes payment. In such cases, the Treasury insists that accrual basis taxpayers recognize income no later than the time when the services have been rendered. Also, the Treasury compels cash-basis taxpayers to shift to the accrual method in cases where inventories are used. ${ }^{27}$

In the prepaid income area, the Treasury obviously cannot use its practical reasons to counter the apparent statutory mandate that allows

${ }^{25}$ Treas. Reg. \$ 1.451-3 (1957).

${ }^{20}$ The Treasury had allowed deferral of prepaid newspaper subscription prior to the statutory provisions, I.T. 2080, III-2 CUM. BuLL. 48, but later reversed its position. Cruise tickets were privileged by I.T. $3369,1940-1$ Cum. BuLL. 46.

${ }_{27}$ Treas. Reg. \& 1.446-1 (c) (ii) (1957). 
tax reporting in accordance with sound accounting methods. A legal argument must be utilized for this purpose. This legal argument has been provided in the form of two related theories, neither of which, in the writer's opinion, supports the Treasury's position. One of these theories has a statutory basis; the other is judicially developed. Both have been the subject of Supreme Court interpretations. A fundamental understanding of each is essential to any further analysis.

VI

The Concept of the Annual Accounting Period

Section 44I of the 1954 Internal Revenue Code provides that taxable income shall be computed on an annual basis. The Internal Revenue Service has used this requirement as an argument that advance receipts must be reported in full as income in the taxable year of receipt, irrespective of whether services have been rendered or goods delivered in such year. ${ }^{28}$ The Service supports this position from its interpretation of Supreme Court decisions in this area.

The leading Supreme Court decision on the concept of the accounting period is Burnet v. Sanford $\mathcal{E}^{2}$ Brooks Co. ${ }^{29}$ There, taxpayer had been employed on a dredging contract with the United States and subsequently sued for breach of warranty concerning the type of bottom to be dredged. Taxpayer's expenses had exceeded its profits during the period of dredging, I9I3 to 1916. In 1920, taxpayer was successful in its litigation and in that year received an additional sum to compensate it for the losses incurred, together with interest. Taxpayer did not report the principal sum received in 1920 as income for that year on the theory that the dredging transaction, viewed as a whole, did not result in any profit. The Commissioner maintained that the entire amount received was income in 1920. The Board of Tax Appeals sustained the Commissioner. ${ }^{30}$ The Fourth Circuit Court of Appeals reversed, holding that only the interest should be included in 1920 income, provided the I9I3 to I9I6 returns were amended to eliminate the loss deductions taken in those years. ${ }^{31}$ The Supreme Court again reversed and reinstated the opinion of the Board of Tax Appeals. In essence, the Supreme Court stated that the federal income tax laws were

\footnotetext{
${ }^{28}$ Brief for. Defendant, pp. 10-12, American Automobile Association v. United States, I8I F. Supp. 255 (Ct. Cl. 1960).

282 U.S. 359 (I 931 ).

${ }_{35}^{31}$ F.2d 3 12 (4th Cir. 1929).

${ }^{30}$ II B.T.A. 452 (I928).
} 
based on an annual accounting period and that it would be impossible to have any workable income tax system if the revenue authorities were compelled to wait until the end of a transaction before assessing a tax. This result is obviously sound. No practical system for the collection of revenue could operate on any other basis.

The Sanford E Brooks doctrine was reaffirmed in "Heiner $v$. Mellon. ${ }^{32}$ There, taxpayer was a partner in a partnership formed to liquidate a corporation in the whiskey-distilling business. In 1920, a gain was realized by the partnership from the sale of whiskey, but taxpayer did not report any income since the liquidation had not been completed and the over-all result of the liquidation might be a loss. The Supreme Court sustained the Commissioner in requiring that the I920 gain realized had to be reported in that year. Again, the result is clearly sound.

However, the Service's attempt to apply the doctrine of the Sanford $\mathcal{E}$ Brooks and Mellon cases to the area of advance receipts for future services is an unsound and illogical extension of that doctrine.' These cases merely held that any amounts earned in a particular annual accounting period must be reported, in the best ascertainable manner, at the end of that period, and that the taxpayer cannot wait until the end of the transaction involved to report his ultimate gain or loss. The Service's interpretation of these cases is that the annual accounting period requires not only that the amounts earned during year I, but any amounts received in year $\mathrm{I}$ be reported as gross income for that year. Not only is this an undue extension of the principle of the annual accounting period, but the Sanford E Brooks case itself contains dictum to the contrary. ${ }^{33}$ The Supreme Court recognized that under the accrual method of accounting authorized by the Internal Revenue Code, current expenses could be used to offset amounts received in another year and that the annual reporting requirement was not designed to nullify this matching of income with expenses.

A proper application of the annual accounting concept to the dancing school illustration posed previously requires inclusion in Z's gross income for year I of the amount earned in that year, as best as can be estimated on December 3r. Since the contract entered into was for twenty-four lessons and the contract price was $\$ 240$, this means that if the contract were completed by both sides, and assuming each lesson

\footnotetext{
${ }^{32} 304$ U.S. $271(1938)$..

${ }_{23}^{38}$ U.S. at 366 .
} 
to be of equal value, then each lesson would cost the student $\$$ IO. By December $3 \mathrm{I}$, ten lessons had been given, so $\$ 100$ should be included in $Z$ 's gross income. This is the result required, despite the fact that subsequent events showed that the student received twenty lessons and paid a total of $\$ 220$, so that viewed as of the close of the transaction, each lesson cost him $\$ I I$, and $\$ I I O$ would be the amount properly includible in $Z$ 's gross income. But the very thing the Sanford \& Brooks doctrine does not permit is to wait until the transaction is over before computing the income attributable to the prior period. So here is one case where the doctrine works in the taxpayer's favor. It might be objected that any sound businessman in the position of the dancing school proprietor would require that the level of payments by the student be in excess of the per lesson charge, so that the school benefits by any default by the student, rather than losing. While this is undoubtedly true as a business matter, it does not follow that any tax consequences should depend thereon. The presumption is that the student will finish his course, and this should be the basis for computing the income earned as of the close of the first taxable period. Moreover, the annual accounting concept in most cases works in favor of the Government, such as where the Commissioner requires a taxpayer to change from a cash basis to an accrual basis because he uses inventories in his business.

It should be apparent from the foregoing that the doctrine of the annual accounting period does not impose any requirement that advance receipts should be reported in full as income in the year of receipt where services remain to be rendered or goods remain to be delivered.

\section{VII}

\section{The Claim of Right Doctrine}

The other doctrine upon which the Treasury relies to support its argument that advance receipts are taxable no later than the year of receipt is the judicially developed doctrine known as "claim of right." An initial question should occur: "How can a judicial doctrine prevail over a statutory requirement where there is a conflict between the two?" The function of a court is to interpret the statute, not to rewrite it, and certainly not to develop a doctrine in clear conflict with it. This question does not appear to have ever been specifically raised. In any event, it will be seen that the claim-of-right doctrine, as properly in- 
terpreted, does not conflict with the statute, and does not support the Treasury's position.

The doctrine was first announced in North American Oil Consolidated v. Burnet. ${ }^{34}$ There, taxpayer and the United States were engaged in a dispute over title to certain oil lands. In 1916 a receiver was appointed to supervise the operation of the properties and to hold the income therefrom pending settlement of title. In 1917 the amounts held by the receiver were awarded and paid to the taxpayer pursuant to a District Court determination that title was in the taxpayer. The United States appealed, and the Supreme Court finally disposed of the title question in taxpayer's favor in 1922. The taxpayer did not return the amounts received as income until 1922 on the theory that the award might have to be returned at any time prior to the ultimate Supreme Court determination. The Commissioner maintained that the amounts turned over had to be included in income in 1917 , when received. The Supreme Court agreed with the Commissioner, stating: ${ }^{35}$

If a taxpayer receives earnings under a claim of right and without restriction as to its disposition, he has received income which he is required to return, even though it may still be claimed that he is not entitled to retain the money, and even though he may still be adjudged liable to restore its equivalent.

It should be noted that the Supreme Court referred to earnings received under a claim of right, and not receipts. In the actual facts before it, the taxpayer's award represented profits earned from the oil lands in 1916. The income-producing activity had taken place prior to the receipt of money by the taxpayer in 1917. This situation is in contrast to the case where a taxpayer receives payment prior to the occurrence of the income producing activity.

How an accountant would treat a sum received under the facts of North American Oil Consolidated is not ascertainable from reference to the accounting authorities. Probably, the treatment would depend upon the evaluation by the accountant as to the degree of likelihood that the money would have to be returned. If the chances of keeping the money were substantial, then probably the accountant would include the receipt in the income of the year received, with a footnote to the financial statements that the possibility existed that such sum might have to be returned. If such were the case, then the result reached by the Supreme

\footnotetext{
${ }^{36} 286$ U.S. 417 (1932).

${ }^{35} I d$. at 424 .
} 
Court could be achieved by a reference to standard accounting practices, as required by statute, and there would be no need for a separate judicial doctrine. It must be recognized, however, that there would also be instances where a taxpayer received earnings under a claim of right, but the chances of retaining the amounts received appeared slight enough so that the proper accounting treatment would be to create a realistic reserve against income at the time of receipt in interest of conservatism. In such case, the claim-of-right doctrine would have independent significance, and the question would be raised whether the claim-of-right doctrine were in conflict with the statute referring to accounting treatment, rather than being an interpretation thereof.

At any rate, it is clear that the original Supreme Court case enunciating the claim-of-right doctrine limited its application to earnings received under a claim of right, and did not extend to all receipts received under a claim of right. Subsequent Supreme Court decisions similarly limited the doctrine's application. Thus, Brown v. Helvering, ${ }^{36}$ Security Flour Mills Co. v. Commissioner, ${ }^{37}$ and United States v. Lewis, ${ }^{38}$ were all cases where services for which the payments were made had been rendered no later than the year of receipt. The Supreme Court case that has come closest to holding that claim of right applied to a receipt of funds prior to the rendition of services is Automobile Club of Michigan v. Commissioner. ${ }^{39}$ There, taxpayer received dues from its members throughout each taxable year. Taxpayer deferred a portion of the dues received to the succeeding taxable year on the theory that a portion of the services for which the dues were paid would be rendered in the succeeding year. The Commissioner sought to require the taxpayer to include the entire amounts received in taxable income when received. The Supreme Court upheld the Commissioner on this issue, but probably based its decision upon the failure of the taxpayer to prove that its system of deferral accurately reflected income, rather than upon the claim-of-right doctrine or any other legal principle. ${ }^{40} \mathrm{~A}$ re.cent Supreme Court decision referring to the Michigan Club case lends support to this view. ${ }^{11}$

${ }^{30}$ 29× U.S. 193 (1934).

38340 U.S. 590 ( $195 \mathrm{r}$ ).

${ }^{37} 321$ U.S. 281 (1944).

${ }^{30} 353$ U.S. 180 (1957).

so The majority's failure to state the basis of its decision has been the cause of much confusion, as will be seen. The dissenting justices were convinced that the claim-ofright doctrine was not the basis of the decision. Id. at 192,193 .

${ }^{41}$ In Commissioner v. Hansen, 360 U.S. $446,+67$ (1959) the Court stated: "The Commissioner has broad powers in determining whether accounting methods used by a 
VIII

The Treatment of Prepaid Items by the Lower Courts

There has been no consistent pattern of treatment for prepaid items in the lower federal courts. The Supreme Court's ambiguously worded decision in Automobile Club of Michigan failed to provide the needed guide toward a proper statutory interpretation. The only forum that has evolved a consistent rule is the Tax Court, and that rule, as will be seen presently, is based on convenience rather than logic.

The early Board of Tax Appeals' opinions in this area were more favorable to taxpayers than were those of the appellate courts. Thus, the Board in the North American Oil Consolidated case held for the taxpayer, ${ }^{42}$ only to be reversed by the Ninth Circuit Court of Appeals, ${ }^{43}$ whose opinion was affirmed by the Supreme Court. Likewise, in the Security Flour Mills case, the Board's holding in favor of the taxpayer ${ }^{44}$ required reversal by the Tenth Circuit, ${ }^{45}$ whose opinion the Supreme Court also affirmed. There were instances where the Board's allowance of deferral was proper under the statutory interpretation suggested here, with its reference to accounting standards. ${ }^{40}$ But in the Board's waning days, and in the Tax Court's beginnings, a change of attitude came about, manifested by a pair of decisions that disallowed deferral in instances where proper accounting would have dictated the opposite result. ${ }^{47}$ There is some evidence that there was not a complete reversal in attitude as late as 1948.48

Any notions that the Tax Court would allow deferral if proper accounting required such a result were put to rest in its decision in Curtis $R$. Andrews. ${ }^{40}$ The facts of that case were remarkably similar to those in the dancing school illustration given earlier. The Tax Court in Andrewes required that the entire sums received by the taxpayer be reported as income in the year of receipt, on the strength of the claim-

taxpayer clearly reflect income." The Michigan Club case is cited as authority for this proposition, indicating that Micligan Club is now viewed by the Supreme Court as a decision based at least in part upon the taxpayer's failure to show that his method of deferral accuratetly reflected income.

${ }^{27}$ I2 B.T.A. 68 (1928).

1445 B.T.A. 67 I (1941).

s3 50 F.2d 752 (9th Cir. 1931).

45 135 F.2d 165 (10th Cir. 1943). (1930).

"Sophia M. Garretson, 1o B.T.A. 1381 (1928); Summit Coal Co., 18 B.T.A. 983

${ }^{77}$ The E. B. Elliott Co., 45 B.T.A. 82 (194r); Your Health Clnb, Inc., 4 T.C. 385 (1944).

${ }^{48}$ Veenstra \& DeHaan Coal Co., ri T.C. ${ }_{964}$ (1948).

${ }_{23}^{49}$ T.C. 1026 (1955). 
of-right doctrine; despite the fact that the taxpayer was legally obligated to provide services in the following year. Since that decision, the Tax Court has consistently held that any item of receipt with respect to future services constitutes income no later than the year of receipt. So firmly does the Tax Court adhere to this doctrine that it has evolved the following rule of law that it applies to these situations: ${ }^{50}$

An item of income cannot accrue for tax purposes after it has in fact been received subject to the unrestricted use by the taxpayer.

This rule makes it impossible to rationalize current Tax Court decisions with the statutory reference to accounting methods on the ground that the taxpayer has failed to prove that his method of deferral accurately reflects income. Certainly, a complete rewriting of sections 446 and $45 \mathrm{I}$ has been accomplished. The claim-of-right doctrine, which assisted the Tax Court in achieving this masterpiece of judicial construction, is no longer even relied upon in Tax Court opinions. ${ }^{51}$ And while it might be thought that the above-quoted statement is the limit of taxability that could be imposed upon a taxpayer with respect to the time when items of prepaid income must be reported, in the actual dancing school case used for illustration, the Tax Court required the taxpayer to report not only the $\$ 180$ received during year $\mathrm{I}$, but the entire contract price of $\$ 240$, even though that sum would never, in fact, be received by the taxpayer because of the student's later default. ${ }^{52}$ This case is believed to be an aberration even under the Tax Court's rule.

The course of the appellate decisions in the prepaid income area is more difficult to chart because there has been little harmony among the circuits, or even within some particular circuits. Again, it is not the writer's purpose to restate the facts of the many decisions by the circuit courts in this area. It should be sufficient to point out that several early appellate decisions applied the claim-of-right doctrine within its proper sphere, ${ }^{53}$ while others extended it beyond this sphere with varying degrees of justification. ${ }^{54}$ Of the recent cases, the first one of crucial sig-

\footnotetext{
${ }^{\text {to }}$ Automobile Club of New York, Inc., 32 T.C. 906, 913 (1959).

${ }^{* 1}$ See, e.g., Streight Radio \& 'Television, Inc., 33 T.C. 127, 137 (1959), aff'd, 280 F.2d $88_{3}$ ( 1960 ).

${ }^{85}$ Mark E. Schlude, 32 T.C. 1271 (1959), rev'd, 283 F.2d 234 (1960).

${ }^{53}$ Blum v. Helvering, 74 F.2d 482 (D.C. Cir. 1934); Fairmount Creamery Corp. v. Helvering, 89 F.2d 810 (D.C. Cir. 1937).

*t Detroit Consolidated Theatres, Inc. v. Commissioner, $1_{33}$ F.2d 200 (6th Cir. 1942) and Booth Newspapers, Irc. v: Commissioner, 201 F.2d 55 (6th Cir. 1952), were cases of cash-basis taxpayers. Hirsch Improvement Co. v. Commissioner, I43 F.2d
} 
nificance was Beacon Publishing Co. v. Commissioner. ${ }^{55}$ There, the Court of Appeals for the Tenth Circuit had before it the propriety of deferring prepaid subscription receipts that a newspaper received in taxable periods prior to those in which the newspapers were to be delivered. Under the analysis so far made, it seems clear that the receipts should not be reflected in income until the income producing activityi.e., delivery of the newspapers-had been accomplished. This was the holding of the Court of Appeals, reversing the contrary holding of the Tax Court. This decision was cited with approval when Congress passed the special statutory provision allowing deferral of prepaid subscription income. ${ }^{56}$

Following Beacon came Schuessler v. Commissioner. ${ }^{57}$ There, an accrual basis taxpayer was in the business of selling furnaces. With each furnace sold, taxpayer guaranteed to turn the furnace on and off at the beginning and end of each winter for a period of five years. The taxpayer received the complete purchase price for the furnace and guarantee at the time of sale. In order to postpone recognition of the entire receipt as income at the time, he set up expense reserves to reflect the estimated expense of turning the furnace on and off during ensuing years. The Fifth Circuit Court of Appeals permitted the taxpayer to use this method of reporting, reversing the Tax Court holding to the contrary. Of particular interest with respect to both of these last mentioned cases is the fact that the Supreme Court specifically refrained from passing upon their correctness when it decided Automobile Club of Michigan. 58

Two recent cases in the area decided by the Second Circuit Court of Appeals are very significant. In one of these cases, Bay Shore Gardens, Inc. v. Commissioner, ${ }^{59}$ the taxpayer had received a premium payment for the full term of a thirty-two-year mortgage loan, and deferred the premium over the period of the loan. From an accounting point of view, the propriety of this treatment could not be questioned. Clearly the payment was received for a thirty-two-year loan, and since interest is

912 (2d Cir. 1944) and New Capital Hotel, Inc. v. Commissioner, 261 F.2d 437 (-6th Cir. 1958) were cases where the payment deferred was that attempted to be attributed to the last year of a long-term lease, obvious cases of manipulation. South Dade Farms, Inc. v. Commissioner, 138 F.2d $8 \times 8$ (5th Cir. 1943 ), on the other hand, is a case that is not justifiable on any such basis.

${ }^{61} 218$ F.2d 697 (roth Cir. 1955).

${ }^{6 \pi} S$. REP. No. 1983,85 th Cong., $2 d$ Sess. 43 (1958).

${ }^{57} 230$ F.2d 722 (5th Cir. 1956). $\quad{ }_{353}$ U.S. $180, \times 89$ n.20.

${ }_{207} 6.2 d 55$ (2d Cir. 1959). 
generally deemed to accrue day by day, it was possible to determine with mathematical accuracy what portion of the premium was attributable to each taxable period. A serious problem of collectibility may have been present, however, because of the long period of time involved. The Commissioner, relying on the claim-of-right doctrine, sought to tax the entire premium in the year of receipt. The Tax Court, in accordance with its own rule, sustained him. ${ }^{60}$ The Court of Appeals reversed, pointing out that the claim-of-right doctrine was not intended to apply to this type of situation, and allowed deferral because this was the accepted accounting practice. The Internal Revenue Service has now acquiesced in this decision. ${ }^{\text {"1 }}$

In Bressner Radio, Inc. v. Commissioner, ${ }^{62}$ a somewhat more difficult factual situation confronted the court. The taxpayer was in the business of selling television sets and other electrical equipment. In order to induce customers to purchase television sets, taxpayer offered a service contract to the customer whereby taxpayer agreed to service the set for a period of twelve months following the sale. Taxpayer introduced substantial evidence showing how much labor and parts costs were required under the average service contract, and how the labor and parts costs were allocated between initial installation and each subsequent service call. Based upon this allocation, taxpayer took twenty-five per cent of the service contract price into income when received and spread the balance over the ensuing twelve-month period of the contract. The Commissioner relied upon the claim-of-right doctrine and introduced no countervailing evidence. The Tax Court, once again, sustained the Commissioner. ${ }^{63}$ The Court of Appeals, in a carefully reasoned opinion, found that taxpayer's evidence established that the method of reporting income did clearly reflect income and that neither the claim-of-right nor any other doctrine required taxpayer to report advance receipts as income until it could be determined whether a profit was earned. The court, after reviewing the Supreme Court's decision in Automobile Club of Michigan v. Commissioner and other claim-of-right cases, concluded: ${ }^{64}$

Therefore there is no basis whatever . . . for the Commissioner's broad assertion that for tax purposes concededly unearned receipts must be regarded as income in the year of receipt, and there is nothing to indicate that in con-

\footnotetext{
${ }^{\circ 0} 30$ T.C. 1292 (1958).

${ }^{02}$ Rev. Rul. 59-422, 1959-2 Cum. Bull. 45x.

${ }^{02} 267$ F.2d 520 (2d Cir. 1959). 28 T.C. 378 (1957).

o4 267 F.2d 520, 528 (2d Cir. 1959).
} 
struing $\S 41$ and 42 and their predeçessors the Supreme Court has generally .departed from the standard of sound accounting practice in determining what methods are authorized under $\S 4 \mathrm{I}$.

Thus, the Second Circuit has boldly departed from the rule adhered to by the Tax Court, basing its decision upon a fresh analysis of the fundamental statutory principles involved. The Internal Revenue Service was so aggravated by the decision that it issued a ruling stating it would not follow the decision. ${ }^{65}$ The Department of Justice failed to apply for certiorari, however, perhaps afraid that an adverse Supreme Court decision would completely destroy the Government's position in the whole prepaid income area.

In the meantime, several other appellate decisions have been handed down. The Court of Claims denied the right to deferral in American Automobile Association v. United States, ${ }^{\circ 6}$ where the taxpayer deferred membership dues on a pro-rata monthly basis, proving by expert accounting testimony that such deferral was the only acceptable method of reporting income for sound business accounting purposes. The Court of Claims also denied the right to deferral of membership dues in New Jersey Automobile Club v. United States, ${ }^{6 \pi}$ a companion case in which the taxpayer failed to prove that its method of deferral was accurate from an accounting standpoint. The Court of Claims considered itself bound by Michigan Club in both cases, but in the New Jersey Club case, the court discussed in detail why the method of deferral used by the taxpayer did not accurately match items of receipt with corresponding expenses, whereas such discussion was carefully avoided in American Automobile Association. Both taxpayers petitioned for certiorari. The Supreme Court granted the petition in American Automobile Association over the opposition of the Solicitor General's office. ${ }^{68}$

Subsequent to the two Court of Claims decisions, the Court of Appeals for the Seventh Circuit, in Streight Radio and Television, Inc.

${ }^{65}$ Rev. Rul, 60-85, 1960-10 INT. REv. BulL. 14.

${ }^{\circ}{ }_{1} 1$ F. Supp. 255 (Ct. Cl.) cert. granted, 364 U.S. 813 (1960). The court's finding of fact (22), not reported in the federal reporter, states as follows: "The method of accounting employed by plaintiff during the years in issue has been used regularly by plaintiff since $193 \mathrm{I}$ and is in accord with generally accepted commercial accounting principles and practices . ..." The Commissioner's findings of fact were more favorable to the taxpayer, such as: "The taxpayer's method of accounting clearly reflected its income." (Finding 33). "The Government's method of accounting is contrary to generally accepted accounting principles and practices." (Finding 24 ).

${ }^{\circ}$ I 8 I F. Supp. 259 (Ct. Cl. 1960).

${ }^{68}{ }_{34}$ U.S. $813(1960)$. 
v. Commissioner, ${ }^{69}$ denied the taxpayer the right to deferral on facts closely similar to those in Bressner. The court based its decision on the Michigan Club case, mixed together with doses of the claim-of-right doctrine and the annual accounting period concept. Bressner was not cited. Taxpayers petitioned for certiorari, and the Solicitor General did not oppose the petition.

The latest appellate decision on the subject is Schlude v. Commissioner, ${ }^{70}$ from which the dancing school illustration was taken. Here, the Eighth Circuit reversed the Tax Court and held that the taxpayer need only take into current income that portion of his receipts which was "earned"-i.e., for which lessons had been given. The opinion contains a comprehensive discussion of the relevant cases and the inapplicability of the claim-of-right doctrine. The Department of Justice petitioned for certiorari.

Whether or not the Supreme Court grants certiorari in Streight or Schlude, it appears that the time for a dispositive pronouncement on the question is at hand. The American Automobile Association case is scheduled for argument on summary calendar early in $196 \mathrm{r}$.

\section{IX}

\section{The Proper Course of Action for the Judiciary-Interim Solution}

The legal principles, arguments and other considerations have been set forth. It now remains to develop a workable and equitable resolution of the problem. Depending upon which branch of government is confronted therewith, the course of resolution will vary. First to be considered is the judicial branch.

We start with the principle that the function of a court of law is to decide cases coming before it by applying reasoned principles of law to the facts. This principle does not necessarily require a holding either in favor of the taxpayer or in favor of the government in a Bressner or American Automobile Association factual situation. It does, however, require that the opinion be based upon sound reasoning. The Bressner decision, it is submitted, meets this test admirably. American Automobile Association, Streight Radio, and the long line of Tax Court decisions, it is further submitted, fail to meet that test.

The latter cases fail to meet the test because they ground their decisions upon either or both of two doctrines, the annual accounting period

\footnotetext{
${ }^{09} 280$ F.2d 883 (7th Cir. 1960).

${ }_{20}^{70}$ F.2d 234 (8th Cir. 1960).
} 
concept and the claim-of-right doctrine, which do not require or even support the result reached. Moreover, these decisions completely ignore the governing statutory language, an egregious $\sin$ in federal tax cases. Where the statute refers to methods of accounting, and the Treasury Regulations further speak of generally accepted accounting principles, it takes a long judicial leap to interpret this language as the Treasury wants it interpreted-namely, that prepaid receipts for future services must be reported by cash and accrual-basis taxpayers alike no later than the time of receipt, irrespective of business accounting doctrines to the contrary. The courts rendering decisions in favor of the Treasury are unquestionably influenced by several considerations apart from the annual-accounting-period concept and the claim-of-right doctrine, although these added factors usually do not find their way into the published opinions. The added considerations, which have been referred to previously, are summarized herewith.

First is the congressional repeal of sections 452 and 462 , coupled with the enactment of section 455 . These events form the basis of an argument in favor of the Treasury that, in the writer's opinion, is more respectable than arguments based upon the annual-accounting-period concept or the claim-of-right doctrine, but still should not be of controlling significance. In brief, the argument points out that Congress repealed two sections that provided specific authorization for deferral in accordance with sound business accounting practices and enacted a section granting such relief for only newspaper and magazine publishers. Therefore, goes the argument, Congress did not intend accrual-basis taxpayers in general to have the benefits of deferral. At first blush, the argument has a good deal of force. However, examination of the statutory provisions that Congress did not repeal, together with the legislative history surrounding sections 452 and 462 , deprives the argument of much of this force.

Section 446(a) states that: "Taxable income shall be computed under the method of accounting on the basis of which the taxpayer regularly computes his income in keeping his books." Section 45I(a) provides for the inclusion of items of gross income according to the "method of accounting used in computing taxable income, . . " Furthermore, the Treasury's own regulations have throughout referred to tax reporting in accordance with methods of accounting that are generally accepted in a particular trade or business. ${ }^{71}$.

\footnotetext{
${ }^{71}$ Treas. Reg. \& r.446-I(a)(2) (r957).
} 
The legislative history at the time of enactment of sections 452 and 462 shows that Congress was dissatisfied that some courts were not permitting deferral of prepaid items in accordance with sound business accounting practices. ${ }^{72}$ Thus, Congress (i.e., the cognizant Committee members) was aware that the pre-section $452-462$ law was unsettled. When Congress indicated its intent that the law revert to this status, ${ }^{73}$ the only realistic evaluation of the congressional action is that Congress wanted to get rid of the problem and throw it back to the courts. Newspaper and magazine publishers were not treated in so ambivalent a fashion, perhaps because it was an election year.

The second extra consideration operating in favor of the Treasury is that requiring receipts to be taken into gross income in the year of receipt provides a clear and simple rule to administer, whereas permitting receipts to be deferred causes complications. ${ }^{74}$ While it is, of course, true that the fact of payment is a clearly identifiable event reliance upon which would simplify auditing of returns, this fact should again not control the decision in this type of case. The prime reason why it should not is because the statutory language says otherwise. Practical factors do not permit courts to rewrite statutes. Even on the practical level, the Treasury's argument on this point is without much force because in the reverse situation, where an accrual-basis taxpayer's rendition of services precedes receipt of payment, the Treasury requires that income be recognized when the right to receive it has been fixed. ${ }^{75}$ There, no complaints are heard about administrative difficulties of ascertaining when services have been rendered. ${ }^{78}$ More will be said about administrative problems later. For purposes of disposing of the in-

\footnotetext{
${ }^{73}$ Supra notes 18 and 23.

${ }^{73}$ Supra notes 20-22.

74 The government counsel in prepaid income cases usually bring this consideration to the court's attention. See Brief for Defendant, p. 20, American Automobile Association v. United States, 18 I F. Supp. 255 (Ct. Cl. 1960).

${ }^{76}$ Treas. Reg. \$ 1.446-1 (c) (1) (ii) (1957).

${ }^{70}$ The truly ironic situation occurred in Pacific Grape Products Co. v. Commissioner, 219 F.2d 862 (9th Cir. 1955), where the classic roles of taxpayer and Commissioner were reversed. Taxpayer, on an accrual basis, was a canner of fruit. The season ran from July through November. During the year, contracts were entered into during the canning season and shipped thereafter. Some of the goods contracted for but not shipped at the close of the taxable year were billed to customers and set aside. Taxpayer recognized the income from these contracts prior to shipment, but the Commissioner argued that no income arose until title passed. The Tax Court, in 17 T.C. I097 (1952), with its customary subservience to the Commissioner in this area, upheld him, but the Ninth Circuit reversed.
} 
stant argument, it is completely untenable for a court to interpret general language as in sections 446 and $45 \mathrm{I}$ to operate only in favor of the Treasury and not the taxpayer.

The third additional consideration influencing courts is the notion that there is not really any great taxpayer hardship involved anyway, so that there is no compelling reason to upset the Commissioner's determination. This theory reasons that once a business gets established, incoming receipts and expenses will be more or less constant, so that it does not matter which year's receipts are offset by which expenses. The argument is illusory because it rests upon two unreal assumptions: first, that the initial year of reporting can be disregarded (where receipts are collected with no offsetting expenses); and second, that receipts will usually be relatively constant from year to year. The fact is that if the first year is disregarded, the Treasury is able to collect a tax on unearned income that the taxpayer cannot recover until he goes out of business or receipts decline. Also in the case of a growing business, the Treasury collects more and more tax on unearned income, again not to be recovered by the taxpayer until he goes out of business or receipts decline. This can produce great hardship for a taxpayer.

As an extreme illustration of such hardship, the $Y$ Company's missile contract case (see page 230 supra) with some added assumptions can be used. Suppose that $Y$ Company incurs no substantial expenses in year I against which to offset its $\$ 1,000,000$ receipt and that the Treasury Regulations on long term building and construction contracts either were not in existence or were held not to apply. This means that if $Y$ were a corporation, taxes of approximately $\$ 520,000$ would be due at the end of year I. This leaves $Y$ only $\$ 480,000$ to meet the costs of construction, probably far less than will be required. The construction cannot be completed without additional financing, which may not be possible to obtain. It is true that the relief provided by the Regulations on long-term building and construction contracts would change the tax consequences. But what if $Y$ were a firm of consulting engineers? This is an extreme case, but it does serve to show the potential hardship involved. It is very possible for a taxpayer such as a TV repair business, which must use prepaid receipts to get started, to be taxed out of existence before becoming established.

The final added factor allegedly supporting the Treasury's position is that collecting a tax in the period of receipt insures collectibility. Permiting deferral, it is argued, requires the Treasury to assume the risk 
of the taxpayer's solvency. If deferral were permitted for an unlimited time, this argument could be important, although even there, the present statutory scheme would not appear to consider this fact. Where this argument falls down at the practical level is that taxing unearned receipts, in and of itself, increases the risk of the taxpayer's insolvency because it may deprive him of the funds necessary to perform the services related to those receipts. The time limitation on deferral suggested hereinafter is believed to be a realistic compromise solution.

Summarizing these additional factors, it does not appear that any one, or any combination of them, should influence a court to depart from the statutory mandate of tax reporting in accordance with sound accounting principles. The last three of these considerations, for the reasons indicated, are not proper for judicial consideration, whether or not they might influence congressional thinking. The first argument, based upon repeal of sections 452 and 462 , is proper for judicial consideration, but should, nonetheless, not be persuasive. This is the only respectable ground upon which a court could render a decision in favor of the Treasury where a taxpayer has deferred receipts in accordance with sound business accounting practices. Unfortunately, judicial opinions have not reasoned on this basis, thereby causing unnecessary confusion of thought.

Ideally, the judicial solution should be announced by the Supreme Court. The American Automobile Association case provides a vehicle for a dispositive decision on the question. What the basis for such decision should be has been made clear.

\section{$\mathrm{X}$}

\section{A Suggested Course for Legislative Action- Hope for Ultimate Resolution}

The next branch of government to be considered is Congress. Here is where the hope lies for a long-term satisfactory resolution of the conflicting interests. The judiciary can only evolve piecemeal solutions and cannot lay down broad rules of compromise such as are needed in the area.

Many reasons can be advanced why Congress should act, and act promptly. Much of the inconsistency of judicial decision can be attributed to the ambiguity of congressional action with respect to the repeal of sections 452 and 462 . New legislation was then promised, but it has not been forthcoming. At the present time, a disparity of treatment? 
exists as between taxpayers dependent upon the type of prepaid items that they receive and upon their geographical location. The disparity as to the type of prepaid income exists because of the specific statutory right vested in newspaper and magazine publishers, and because the Treasury grants special favors to certain other groups of taxpayers. ${ }^{77}$ The disparity based upon geographical location exists because of the judicial forum (especially at the appellate level) that decides any litigation.

The foremost principle that should guide the congressional action is that income for federal tax purposes be computed in accordance with sound accounting principles in so far as practically possible. The principles developed by the accounting profession are designed to provide a proper yardstick for measuring net income in order to provide a realistic evaluation of the financial condition of a particular business. One of the cardinal principles developed by the accounting profession is that no income arises until performance is rendered by delivery of goods or rendition of services. In other words, there should be a matching of receipts with related items of cost. This is a sound principle that should be preserved to the greatest extent possible in the federal income tax laws, especially in view of today's high income tax rates. ${ }^{78}$

The cardinal accounting principle having been established, it now remains to adapt and qualify it to meet the practical needs of the Treasury. The need for such qualification is apparent from the legislative history of sections 452 and 462 . It appears that the most objectionable aspects of this prior legislation were twofold:

(I) No transitional rule was provided to curtail the initial drain on the public treasury; and

(2) No provision was present to prevent the creation of artificial and fictitious reserves against income for future expenses.

Both of these objections can be corrected.

As to the first, a transitional rule can be provided that spreads the impact of the conversion year over a reasonable period, such as five years. Drafting of a provision to accomplish this result is not free from

${ }^{77}$ The favored classes of income, in addition to prepaid subscriptions, are longterm building, installation, and construction contracts, and prepaid cruise tickets. Sec supra notes 25 and 26 .

${ }^{78}$ Taxpayers have, on occasion, argued that taxation of advance receipts prior to performance with respect thereto is in violation of the Sixteenth Amendment to the Constitution. Such arguments have been summarily, and correctly dismissed by courts. Automobile Ċlub of New York, 32 T.C. 906, 914 (1959); New Jersey Automobile Club v. United States, 181 F. Supp. 259 (Ct. Cl. 1960). 
difficulty, but it can and has been done. H.R. I 1266 , which failed to be enacted by the 86 th Congress, ${ }^{79}$ provided deferral treatment for certain prepaid membership dues, and contains a method which is workable. Under this method, a taxpayer who defers receipts for the first time will be required to take into gross income for such first year an additional amount equal to that which would have been deferred from prior years if the same method of accounting had been used. One-fifth of this additional amount (which has already been once subject to taxation) is then allowed as a deduction in the first year, and one-fifth in each of the succeeding four years. At the end of the fifth year, the taxpayer comes out whole, having achieved his conversion to tax reporting in accordance with sound accounting principles; and the impact upon the Treasury's revenues has been softened.

The second objectionable aspect, that of the artificial reserves, can be easily met by not allowing any sort of reserve for future expenses to be created against income. No provision comparable to section 462 would be enacted. In other words, one of the two accounting techniques for postponing recognition of income to a future taxable period will not be allowed. As has been indicated previously, either of the postponement techniques, deferral of income or accrual of reserves, achieves the basic accounting concept of matching receipt with related expense. Accrual of reserve achieves the matching in an earlier period than deferral of income. No great hardship is imposed upon taxpayers with respect to prepaid items by permitting only the deferral technique; and the interests of the Treasury are greatly advanced by so doing. It is true that there will be cases where taxpayers will be unable to report income in accordance with sound accounting principles because of the absence of section 462 , but this is a concession that should be made to the Treasury.

A third restriction that should be placed upon sound accounting principles in the new legislation is the period over which deferral would be allowed. Section 452 and 462 limited the period of deferral to five years beyond the date of receipt. This seems a wise limitation to preserve the Treasury's interest in collectibility. ${ }^{80}$

\footnotetext{
${ }^{70}$ H.R. I1266 was passed by the House of Representatives in the late stages of the second session, bnt was not passed by the Senate.

${ }^{80}$ The problem of deferral over long periods of time has arisen chiefly with respect to security deposits on long-term leases. The lessor usually exacts an amount equal. to one year's rental at the commencement of the lease and terms this amount the rental for the last year of the lease. The last year of the lease may be 10, 20 or even 99 years
} 
With these restrictions, legislation permitting deferral of income in accordance with sound accounting principles is both desirable and practical. There appears to be no reason why section 452 , with the addition of the transitional rule borrowed from H.R. I 1266, could not be used to accomplish this result. If this were done, the income tax laws would be brought into harmony with sound accounting principles so that income for tax purposes would be computed on an equitable basis consistent with the practical needs of the Treasury. The legislation should also provide that the deferral of income would be on an elective basis, so that an accrual-basis taxpayer who chooses to report income from advance receipts at the time of receipt could do so and still use the accrual method for other purposes.

\section{$\mathrm{XI}$}

Administrative Problems Created by the Suggested Legislation

If legislation along the lines suggested were enacted, new problems of administration would be created for the Internal Revenue Service. Recognizing the principle that income should be taxed only as it is earned is far different from making a determination as to whether or not a particular taxpayer's method of reporting income is in accordance with that principle. It is unquestionably true that the rule suggested would be more difficult to administer than the present one. Yet, this is not a persuasive reason against adopting the rule. If ease of administration were the controlling criterion in evaluating the desirability of revenue measures, it would be well to eliminate deductions altogether and tax gross receipts. It is clear that administrative diffculties must give way to equitable principles when the two conflict. Such is the case here.

Nor will the administrative problems be insurmountable. Treasury Regulations can be used to provide assistance for taxpayers and revenue agents alike as to what requirements must be met before a method of deferral will be regarded by the Treasury as clearly reflecting income. Specifically, these Regulations could set forth the records which a taxpayer would be required to keep in order to substantiate the accounting accuracy of his deferral method. In all probability, most taxpayers

in the future. The Treasury Regulations specifically require inclusion of such amounts in income in the year of receipt. Treas. Reg. $\$ 1.61-8(b)$ (1957). Where an "advance rent" is in substance a security deposit, it would seem equitable to allocate "such" süm rátably over the maximum period allowed for deferral. 
electing deferral of advance receipts would do so on a ratable monthly basis, which would keep audit problems for revenue agents manageable. Since agents are trained at least to some extent in accounting practice, their added burdens. from this legislation would not, be impossible to bear. Agents are often confronted with more complex audit problems, as in the inventory area.

From the taxpayer's standpoint, if the record-keeping requirements imposed by the Regulations are too onerous, the simple way out is not to elect deferral under the new provision.

In conclusion, it is not expected that implementation of tax reporting in accordance with sound accounting principles will be achieved without administrative complications, or without some initial litigation as to what type and degree of proof must be adduced to show that a system of deferral is in accordance with sound accounting principles. This is not a compelling reason against enactment of the rule, for the principle is worth such difficulties. 